\section{Paperback Polymorphism}

SiR,-D. F. Owen comments (Nature, 245,343 ) on the variety of colours in which R. A. Fisher's The Genetical Theory of Natural Selection is available in paperback, and speculates that Fisher " . . would have been delighted to hear that the polymorphism in the paperback edition of his classic work had possibly affected its sales".

I happened to be with Fisher when he opened the parcel containing the first copies of the paperback edition that he had seen: he took one look at the cover (red) and said "Looks like a book by Hogben."

Yours faithfully,

A. W. F. EDWARDS

Gonville and Caius College,

Cambridge $C B 2 \quad 1 T A$

\section{Announcements}

\section{University News}

Heriot-Watt University has conferred the title of Professor Emeritus upon Dr Walter G. Green.

The University of St Andrews has appointed Professor Vincent Bruce Proudfoot to the newly established Chair of Geography.

\section{Appointments}

Mr Alan V, Holden has been appointed Officer in Charge of the Freshwater Fisheries Laboratory of the Department of Agriculture and Fisheries for Scotland at Pitlochry.

Professor J, Gani, Director of a combined school of the Universities of Sheffield and Manchester, has been appointed Chief of the CSIRO Division of Mathematical Statistics.

Dr G. F. Humphrey, Officer in Charge of the CSIRO Marine Biochemistry Unit, has been elected Chairman of UNESCO's Intergovernmental Oceanographic Commission.

\section{Miscellaneous}

The Zoological Society of London has awarded the first British Zoologist's Medal to Sir Julian Huxley.

A British Society for Population Studies has been set up to continue and expand the scientific study of population questions. The chairman is Professor D. V. Glass of the London School of Economics and Political Science, Houghton Street, Aldwych, London, WC2A 2 AE.

The 1973 Soviet State Prizes for science were awarded as follows: to Nikolai $\mathbf{A}$. Borisevich and Viktor G. Vereshchagin for studies of radiation scatter by dispersion systems and the development of a new wide-range infrared filter; to Marat I. Adamovich, Boris B. Govorkov, Anatolii S. Belousov, Andrei I. Lebedev, Sergei P. Kharlamov, Evgenii I. Tamm, Acaciemician Anatolii A. Logunov, Lev D. Solov'ev, Aleksandr M. Baldin and Al'bert N. Tavkhelidze for their work on the photogeneration of $\pi$-mesons on nucleons; to Nikolai P. Korneichuk for his work on extremal problems in approximation theory; to Academician Boris P. Nikol'skii, Professor Mikhail M. Shul'ts, Anatolii I. Parfenov, Anatolii A. Belyustin, Vladimir A. Dolidze, Archil N. Khutsishvili, Anatolii S. Benevol'skii, Viktor P. Yukhnovskii, Valentin V. Aleksandrov, Nikolai A. Fedotov and Nikolai A. Izmailov for work on the electrode properties of glasses; to Nikolai G. Rambidi, Yurii S. Ezhov, Petr A.
Akishin, Evgenii Z. Zasorin, Viktor P. Spiridonov and Mikhail I. Vinogradov for developing a new method of hightemperature gas electronography and applying it to study the structure of inorganic molecules at temperatures above $2,500^{\circ} \mathrm{C}$; to Aleksei $\mathrm{D}$. Shcheglov, Deputy Minister of Geology of the USSR, for publications on regional metallogeny; to Academician Innokentii P. Gerasimov, Nikolai F. Leont'ev, Yakob G. Mashbin, Dmitrii A. Lilienberg, Feofan F. Davitaya, Vladimir G. Brugger, Anatolii G. Voronov, Aleksandr M. Ryabchikov, and to Antonio Nuñes-Jimenez, Pedro Cañas-Abril, Salvador Massip-y-Valdes and Juan Torrente del Valle for work in compiling the National Atlas of Cuba; to David M. Golub for work on the development of the nervous system and the theoretical and experimental basis for establishing new nerve links and centres; and to Academician Aleksei P. Okladnikov and Viktor I. Shunkov for their five-volume History of Siberia.

Solutions to Chess Problems
Problem 1: 1. Q-K2 mate.
Problem 2: 1. Kt-Kt6 mate.
Problem 3: 1. Castles (QR), any; 2. R-Q8 mate
The point of this problem is that Black could
have reached the position in the diagram only by
moving his king or rook on the immediately
preceding move. Thus, although White can
legally castle on his own move, Black has
forfeited the right to castle on his move (which
would otherwise have been a complete resource
against the threat of mate).
Problem 4: White's last move must have been $\mathrm{K}$
(from, K3) $\mathrm{P}$ (Q3) giving discovered check.
Black's preceding move to this must have been $\mathrm{P}$
(K5) $\mathrm{P}$ e.p. (Q6) giving double check, and
White's move before this $\mathrm{P}$ (Q2)-Q4. Black's
move before this must have been a bishop move
to QB4 giving check to the White king on K6.
The main 'try' for Whites last move in the posi-
tion in the diagram is $\mathrm{K}$ (frcm Q2)-Q3 giving
discovered check, and Black's preceding move
being $P$ (QB7) $x$ White piece (QN8) K. giving
double check. This solution, however, leads to
an 'illegal' position as there are too many black
pawn captures of white pieces (and pawns)
needed to reach it from the pawn formation of the
starting position of a game of chess.

Problem 1: 1. Q-K2 mate.

Problem 2: 1. Kt-Kt6 mate.

Problem 3: 1. Castles (QR), any, 2. R-Q8 mate. have reached the position in the diagram only by moving his king or rook on the immediately 年, against the threat of mate)

Problem 4: White's last move must have been $\mathrm{K}$ (from K3) X P (Q3) giving discovered check. Q The main 'try' for White's Jast move in the position in the diagram is $K$ (frcm $Q 2$ ) $Q^{3}$ giving (QB $\mathrm{x}$, white piece $(\mathrm{QN} 8)=\mathrm{K}$ t giving double check. This solution, however, leads to starting position of a game of chess.

\section{Subscriptions to NATURE}

Subscription Department, Macmillan Journals Ltd., Brunel Road, Basingstoke, Hampshire RG21 2XS.

Please send me 52 issues of NATURE starting with the issue dated $\ldots \ldots \ldots \ldots \ldots$.

I enclose $£ 16$. USA \& Canada $£ 20$

(Prices applicable only to orders started before 31st December 1973.) (Orders must be accompanied by remittance. Cheques should be made payable to Macmillan Journals Ltd.)

NAME

ADDRESS
Editorial Department

MACMILLAN JOURNALS LIMITED 4 ITTLE ESSEX STREET, LONDON WC2R 3LF Tolephone Number: 01-836 6633. Telegrams: Phusis London WC2R 3LF Telex 262024

MACMILLAN JOURNALS LIMITED

711 NATIONAL PRESS BUILDING

WASHINGTON DC 20004

Telephone Number: 202-737 2355. Telex 64280

Subscription Department

MACMILLAN JOURNALS LIMITED

BRUNEL ROAD, BASINGSTOKE, HANTS RG21 2XS

Telephone Number: Basingstoke 29242

Display Advertisement Department

MACMILLAN JOURNALS LIMITED

4 LTTLE ESSEX STREET, LONDON WC2R 3LF

Telephone Numbers: UK 01-836 6633. USA 202-737 2356

Classified advertisements

T. G. SCOTT \& SON, LIMITED

1 CLEMENT'S INN, LONDON WC2A 2ED

Telephone Number: 01-242 6264/01-405 4743

Telegrams: Textualist London WC2A 2ED

Registered as a newspaper at the Post Office 